\title{
NOTES ON SOME MALLOPHAGAN GENERIC NAMES.
}

\author{
By T. Harvey Johnston, M.A., D.Sc., and Launcelot \\ Harrison.
}

A certain amount of confusion has crept into the generic nomenclature of the Insects belonging to the order Mallophaga. Many of the errors have been corrected by Neumann(1906), but there are, however, a few important points in which we differ from the well known French parasitologist. In order that the matters referred to by us might be more easily understood, a very brief sketch of the previous work on certain generic names in this group is necessary.

The difference between "biting lice" and "sucking lice" was first recognised by De Geer(1778), who founded the genus Ricinus to include the mandibulate forms, the old name Pediculus being retained for the true lice, whose affinities are rather with the Hemiptera than with any other order. Hermann(1804), knowing Ricinus to be preoccupied in Botany, proposed Nirmus as a substitute. Nitzsch, in 1818, published a very important work on parasitic Insecta, including the Mallophaga, but took no notice of previous attempts at classification, beyond placing the earlier generic names as synonyms of his own. He divided the order into two families, to which, however, he did not assign names, these being first given, in 1832, by Burmeister. Each family consisted of two genera, one parasitic on mammals and one on birds. The bird-infesting genera were subdivided by Nitzsch into a number of subgenera as follows :-

Fam. Phicopteride: (1) Trichodectes; (2) Philopterus (subgenera: Docophorus, Nirmus, Lipeurus, Goniodes).

Fam. Lrotheid : (1) Gyropus; (2)Liotheum(subgen.: ColpocehpaIum, Menopon, Trinoton, Eureum, Lamobothrion, Physostomum).

In the case of the two subdivided genera, all species were left in the original genus in each case, but were grouped under the 
headings of the various subgenera. These subgenera, though ostensibly retaining that rank, were practically treated as genera by Burmeister(1832), Denny(1842), Giebel(1874), Piaget(1880, 1885 ), and Taschenberg(1882). It was Kellogg(1896, p.60), who first openly raised the subgenera to genera.

Neumann $(1896$, pp.56, 60) has pointed out that Hermann had no real justification for erecting Nirmus, hence his genus must be ranked as a synonym of Ricinus. Moreover, Nirmus Nitzsch (1818) could not stand, as the name had already been used by Hermann. Neumann accordingly substituted Degeeriella for Nitzsch's genus. He went on to point out that, in the elevation of the subgenera to genera, the original genera had not been retained, and he, therefore, took the first described species under the first named subgenus in each case as the type of the original genus. Thus Docophorus was replaced by Philopterus (with I'. ocellatus Scop., as the type), and Colpocephalum by Liotheum (with L. zebra N., as the type). Finally, he considered the question of reinstating Ricinus. He has credited Piaget with pointing out that the first species described by De Geer, under his genus as Ricinus fringilla, was subsequently included in Physostomum N., whereas that author, as well as Giebel and Denny, have, in this matter, simply followed the synonymy given in Nitzsch's work. Ricinus firingilla De Geer, was made the type-species of the genus by Neumann, and was said to be probably identical with Physostomum irascens N. Nitzsch, Denny, and Giebel have, however, definitely placed $R$. fringillce as a synonym of $P h$. nitidissimum $\mathrm{N}$, admitting the identity of the two forms. No reasons are advanced by Neumann to show that the latter admission is incorrect. We may therefore conclude that Nitzsch's Ph. nitidissimum, rather than his $P h$. irascens, is the same species as that named by De Geer as R. fringilla, and designated as type of Ricinus by Neumann. This author is correct in regarding Physostomum as a synonym of the latter genus; but it appears to us that the fate of the genera Liotheum and Colpocephalum is also dependent on the above facts.

Our view of the matter will be seen from the following statement. De Geer founded the genus Ricinus, but, as no type had 
been designated and all the species had been allotted to later genera, Neumann was at liberty to designate a type from amongst De Geer's original species. R. fringillce having been selected, Physostomum N., becomes a synonym of Ricinus on account of the former including the type-species of the latter amongst its original species. Nitzsch, however, regarded Physostomum as a subgenus, and consistently referred to every species under its generic and not under its subgeneric name. Thus Ricinus fringilla De G., appeared in Nitzsch(1818) as Liotheum nitidissimum. Hence Liotheum N., includes the designated type of the earlier genus Ricinns, and must be ranked as a synonym of the latter. We do not think that it is permissible to fix a type for Liotheum as well as for Ricinus, seeing that the type of the latter is already included in the former. We have consulted papers by Stiles(1905), and Blanchard(1906), but have not noticed any direct ruling on the point involved. Stiles(1905, p.26), in writing of subdivided genera, states that "if a type is designated, the original generic name always follows the subdivision containing the type." Thus R. fringillce must pass into Liotheum before it can reach Physostomum. The last-mentioned must be the typesubgenus (in the Nitzschian sense) of Liotheum, i.e., of Ricinus since it includes the type of the genus. Colpocophalum N., would thus maintain its individuality.

Apart from the question of nomenclatural propriety, there can be no doubt as to the expediency of our view, for we would retain the well known genus Colpocephalum, which included 137 species up to 1908 (Kellogg, 1908), whereas Neumann would reduce it to a synonym of Liotheum, a generic name which has remained practically unused since Nitzsch's day. We would place both Liotheum N., and Physostomum N., as synonyms of Ricinus, thus involving a change in the generic names of the twenty-nine species hitherto included under Physostomum (vide Kellogg, 1908), a change that is inevitable, as has already been pointed out by Neumann. Liotheum Neum., nec Nitzsch, accordingly becomes a synonym of Colpocephalum.

Among certain philopterid genera, an extraordinary confusion has arisen, the various stages of which are as follows. In 1835 , 28 
Dufour described a parasite, Philopterus brevis, from an albatross, this species being made the type of the genus Docophoroides Denny(MSS.) by Giglioli in 1864, a valid generic diagnosis being given. Nitzsch had named the same insect Lipeurus taurus, but since his description was not published until 1866 (p.385), it cannot claim precedence. Subsequent writers apparently recognise these facts in their synonymy, but Denny's genus has not received due recognition. In 1866, Rudow founded Trabeculus for a closely allied parasite, Tr. schillingi, from a petrel; and, four years later, ignoring his own prior action, created a new genus, Oncophorus (nec Oncophora Dies., a nematode genus) with the same type. In 1882, Taschenberg erected Eurymetopus with Lipeurus taurus N., as type, recognised Rudow's Oncophorus schillingi as congeneric, after having examined the type-specimen of the latter, and placed this species under his own genus. Piaget, in 1880, added several species to Oncophorus Rudow, dividing them into two groups, the Docophoroides and the Nirmoides; but he was obviously not too sure of his ground, since, though he included Rudow's species in his descriptions, he did not include it in his key to the genus. Taschenberg having removed $O$. schillingi from the genus Oncophorus into his Eurymetopus, Piaget in 1885 (p.35) claimed the genus as "Oncophorus, m." Kellogg(1896, p.68) has indicated some of these facts, but has not offered any comment, while Neumann appears to have overlooked them, and to have accepted Piaget's genus as being identical with Rudow's Trabeculus, which name he allowed to stand. He gave a new name, Taschenbergius, in place of Eurymetopus, a name already preoccupied as a genus of Coleoptera by Schönherr in 1840. From the foregoing it is obvious that Docophoroides Denny, stands, with Trabeculus Rud., Oncophorus Rud., Eurymetopus Tasch., and Taschenbergius Neum., as synonyms, for the forms from petrels: while a new generic name is required for the species from Rallida, etc., grouped by Piaget and later writers under Oncophorus $(O$. schillingi and allied Docophoroid forms being excluded). For this group of species, we propose the name Rallicola, which differs etymologically from Rallicula Schleg., 1871, in ornithology. $O$. attenuatus $\mathrm{N}$., has been selected by us as the type-species. 
Neumann has already replaced Nitzschia Denny, 1842 (nec v. Baer, 1827) by Dennyus, and Piagetia Picaglia, 1885, (nec Ritsenia, 1874) by Piagetiella. Picaglia's paper is not available to us, and his genus has not been taken into account by Kellogg, beyond the mere mention of it in his bibliography $(1896$, p.36). The species are listed under Menopon in the latter's list (Kellogg, 1908). We are, therefore, not able to give any opinion as to the value of the genus. A subdivision of the unwieldy Menopon is, however, desirable. Eureum N., is included by Neumann in his list of genera, though $\operatorname{Kellogg}(1899, \mathrm{p} .133)$ has shown it to be based on immature forms of a Menopon. The latter author has studied E. malleus N.,(=M. malleus), which, being the better known of Nitzsch's two species, may be taken as the type.

In a later publication, Neumann (1909, p.9, footnote) has changed Ornithobius Denny, to Ornithonomus, as he considers the former name to be preoccupied by Ornithobia Meigen, 1832, in Diptera. In the recommendations under Art.36 of the International Code, as given by Stiles(1905, p.47), and by Blanchard (1906, p.32), this is not allowed to be sufficient grounds for the rejection of a name. We have accordingly placed Ornithonomus Neum., as a synonym of Ornithobius Denny, in the list of genera appended. Piaget (1880, p.378) has already shown that Metapeuron Rudow, (type $M$. punctatum Rud.,=O. cygni L.) is a synonym of this genus.

The following genera, proposed prior to Neumann's paper, have been omitted by him, viz., Nesiotinus Kellogg, 1903; Philoceanus Kell., 1903; Ornicholax Carriker, 1903; Kelloggia Carriker, 1903; Heterodoxus Le Souëf \& Bullen, 1902; Latumcephalum Le Souëf, 1902.

In conclusion, we append a list of the twenty-eight genera at present existing, indicating the types where our available literature has permitted. Such of these types as are marked with an asterisk $\left(^{*}\right)$, have been designated as such by ourselves, and, for the most part, have been selected from the available species on account of their occurrence on common domestic animals, or on other hosts which are fairly readily obtainable. 
A. Suborder Ischnocera Kellogg. F a m. Trichodectida:-

1. Trichodectes N., 1818.—*T. canis Degeer (syn. T. latus N.). F a m. Philopterida:-

2. Philopterus N., 1818 (syn. Docophorus N., 1818)-P. ocellatus Scop.

3. Nesiotinus Kell., 1903.-N. demersus Kellogg.

4. Kelloggia Carriker, 1903.-K. brevipes Carr.

5. Ornicholax Carriker, 1903.-O. robustus Carr.

6. Ak doproctus Piaget, 1878.-A. marginatus $\mathrm{P}$.

7. Giebelia Kellogg, 1896.-G. mirabilis K.

8. Degeeriella Neum., 1906 (syn. Nirmus N., 1818, nec Herm., 1804). - ${ }^{*} D$. discocephalus $\mathrm{N}$.

9. Docophoroides Denny in Giglioli, 1864 (syns. Trabeculus Rud., 1866; Oncophorus Rud., 1870, nec Piaget, 1885 ; Eurymetopus Tasch., 1882 , Taschenbergius Neum., 1906).-D. brevis Dufour.

10. Goniodes N., 1818. - * G. pavonis L. (syn. G. falcicornis N.).

11. Goniocotes Burm., 1835.- * G. gallina Deg. (syn. G. hologaster N.).

1.2. Ornithobius Denny, 1842 (syn. Metapeuron Rud., 1870; Ornithonomus Neum., 1909).-O. cygni Linn.

13. Bothriometopus Tasch., 1882.-B. macrocnemis N.

14. Philoceanus Kellogg, 1903.-P. becki K.

15. Lipecurus N., 1818.—*L. caponis Linn. (syn. L. variabilis N.).

16. Rallicola nobis, 1911 (syn. Oncophorus, Piag., 1885 ; nec Rudow, 1870). - ${ }^{*} R$. attenuatus $\mathrm{N}$.

B. Suborder Amblycera Kellogg.

F a m. Gyropida.

17. Gyropus N., 1818. - * G. ovalis N. 


\section{F a m. Ricinid $\alpha . \dagger$}

18. Ricinus Degeer, 1778 'syns., Nirmus, Herm., 1804, nec N., 1818; Liotheum N., 1818, nec Neum., 1906; Physostomum N., 1818).- $R$. fringilla Deg.

19. Colpocephalum N., 1818 (syn. Liotheum Neum., 1906, nec N., 1818).-C. zebra N.

20. Menopon N., 1818 (syn. Eureum N., 1818).—*M. gallina L. (syns. M. trigonocephalum Olfers; $M$. pallidum N.).

21. Trinoton N., 1818. - ${ }^{*}$ T. anseris Sulzer (syn. T. conspurcatum N.).

22. Lamobothrion N., 1818. - ${ }^{*}$ L. maximum Scop. (syn. L. giganteum N.).

23. Boopia Piaget, 1880.-B. tarsata Piag.

24. Dennyus Neum., 1906 (syn. Nitzschia Denny, 1842, nec v. Baer, 1827).-D. burmeisteri Denny (syn. N. pulicaris N., in Giebel, 1874).

25. Ancistrona Westwood, 1874.-A. procellaria Westw.

26. Piagetiella Neum., 1906, (syn. Piagetia Picaglia 1885, nec Ritsenia).

27. Heterodoxus Le Souëf \& Bullen, 1902.-H. macropus Le Souëf \& Bullen.

28. Latumcephalum Le Souëf, 1902.-L. macropus Le Souëf.

\section{BIBLIOGRAPHY.}

1906, Blanchard - " Règles internat.d.1. Nomencl. Zool. etc." Bull. Soc. Zool. France, xxxi., 1906, pp.15-35.

1832, Burmeister-Handb. d. Entomol. 1832.

1778, DE GEER-Mémoires pour servir à l'histoire des Insectes, vii., p. 69. 1842, Denny-Monogr. Anoplurorum Britanniæ, London, 1842.

1835, Dufour-Ann. Soc. Ent. France, iv., 1835.

1874, GiевеL_-“Insecta Epizoa etc.," Liepzic, 1874.

1864, Giglioli-Q.J.M.S. iv., 1864.

1804, Hermann-Mémoire aptérologique, xii., 1804, p.12.

+Called Liotheince in Neumann(1906, pp.58, 60). Ricinide is the more correct designation, as the name refers to a family whose type-genus is Ricinus. 
1896, KellogG_-“New Mallophaga, i.” Proc. Calif. Acad. Sci.(2), vi., 1896, and in Contributions to Biology from the Hopkins Seaside Lab., iv., 1896.

1899, ___ New Mallophaga, iii." Proc. Calif. Acad. Sci., Occas. Papers, vi., 1899.

1908, __ “ Mallophaga," in Wytsmann's "Genera Insectorum." Fasc. 66.

1906, Neumann-Bull. Soc. Zool. France, xxxi., 1906, pp.54, sqq.

$1909, \ldots+$ - "Parasites et Maladies parasitaires des Oiseaux domestiques." Paris, 1909.

1818, Nitzsch-in Germar's Magazin d. Entom., iii., 1818, pp. 261, sqq. 1866, Zeitschr. f. ges. Naturwiss. xxviii.

1874, - in Giebel's “'Insecta Epizoa,” 1874.

1880, Piaget_-“Les Pediculines, Essai Monographique." Leiden, 1880. 1885, — , , , Supplement. Leiden, 1885.

1884, Picaglia - Atti d. Soc. d. Nat. d. Modena,(3), ii., 1884, p. 103.

1866, Rudow-Zeitschr. f. ges. Naturwiss. xxvii., 1866, p.466.

$1870,-\quad, \quad \quad$, $\quad \quad \quad \quad \quad$ xxxv., 1870, p.138.

1905, Stiles-Bull. 24, Hyg. Lab. Publ. Health \& Mar. Hosp. Service, U.S.A.

1882, Taschenberg-“ " Die Mallophagen etc.' Nova Acta, Halle, xliv., $1,1882$.

Postscript, added 15th July, 1910.-After this paper was read, we came upon a reference in $\mathrm{Kellogg}(1896, \mathrm{p} .164)$ which gives the generic characters of Piagetia, P. ragazzii Picaglia, being the type. This parasite is certainly congeneric with Menopon titan Piaget, and Tetrophthalmus chilensis Grosse(Zeit. f. wiss. Zool., xlii., 1885, p.534). As Grosse's genus Tetrophthalmus antedates Picaglia's Piagetia, which name is, moreover, already preoccupied, as Neumann has pointed out, Grosse's genus must stand (with $T$. chilensis as type), and Piagetia Picaglia, as well as Piagetiella Neumann, must rank as synonyms. We refrain at present from commenting upon the individuality of $T$. chilensis, and the various other species and subspecies of the titan-group (T. titan, Piag., T. ragazzii Pic., T. consanguineus Piag., T. linearis Kell., and T. impar Kell.).

According to the ruling of the International Commission, Grosse's genus Tetrophthalmus is not invalidated by Tetrophthalma Less., 1833(Coleoptera), and Tetraophthalmus de Haan, 1834 (Coleoptera). 


\section{$2 \mathrm{BHL}$ Biodiversity Heritage Library}

Johnston, T Harvey and Harrison, Launcelot. 1911. "Notes on some Mallophagan generic names." Proceedings of the Linnean Society of New South Wales 36, 321-328. https://doi.org/10.5962/bhl.part.21901.

View This Item Online: https://www.biodiversitylibrary.org/item/22901

DOI: https://doi.org/10.5962/bhl.part.21901

Permalink: https://www.biodiversitylibrary.org/partpdf/21901

\section{Holding Institution}

MBLWHOI Library

\section{Sponsored by}

MBLWHOI Library

\section{Copyright \& Reuse}

Copyright Status: NOT_IN_COPYRIGHT

This document was created from content at the Biodiversity Heritage Library, the world's largest open access digital library for biodiversity literature and archives. Visit BHL at https://www.biodiversitylibrary.org. 